\title{
Behavioural Responses of Unio tumidus Freshwater Mussels to Pesticide Contamination
}

\author{
Joanna Chmist ${ }^{1}$ [ $\cdot$ Krzysztof Szoszkiewicz $^{1}$. Dariusz Drożdżyński ${ }^{2}$
}

Received: 17 January 2019 / Accepted: 23 June 2019 / Published online: 4 July 2019

(c) The Author(s) 2019

\begin{abstract}
A pesticide is a chemical substance used for the disposal of pests, such as insects, weeds, invertebrates, or rodents. Pesticides interfere with the normal metabolism of the target species; however, some of them may inadvertently affect organisms other than those targeted. Increased quantities of pesticides in water disturb various ecological processes and may increase the mortality rate of various native species of flora and fauna. One of the groups of organisms that are at the greatest risk from the adverse effects of pesticides is the bivalves. This study was designed to assess the behavioural reaction of bivalves to widespread pesticides. As a representative example, the Polish native Unio tumidus (Philipsson 1788) was used. The study investigated different groups of toxic pesticides, such as herbicides (lenacil), insecticides (thiacloprid, DDT and dichlorvos), and fungicides (tebuconazole), in concentrations of $10 \mathrm{mg} \mathrm{L}^{-1}$. The results showed various behavioural reactions of bivalves to the pesticides. The most evident were activity time and shell opening rate. Moreover, as a result of DDVP contamination, effects were recorded in terms of shell opening level as well as rapid onset of death. Among the five analysed plant protection products, the most toxic was DDVP. Its presence caused adductor muscle paralysis in all analysed individuals. The least toxic pesticides were DDT and thiacloprid. A strong reaction to lenacil was observed especially in the shell opening rate. Tebuconazole caused significant reductions in activity. Despite the fact that the impact of pesticides on ecosystems is under regular observation, with the use of a wide range of scientific techniques, the use of bivalves was shown to have considerable potential for water quality monitoring.
\end{abstract}

Pesticides are among the main stressors in aquatic ecosystems located in agricultural areas (Pathiratne and Kroon 2016). Due to farming, every year more than one million tonnes of fertilizers and pesticides contaminate both surface and groundwater (Cruzeiro et al. 2016; Rodrigues et al. 2018). Increased quantities of pesticides in water disturb various ecological processes and may increase the mortality rate of various native species of flora and fauna (Edwards 2013; Nowell et al. 2014; Serrano et al. 2012).

Levels of pesticides in the environment are increasing year by year. Until the Second World War, only 30 pesticides were known. However, the peak quantity of pesticides

Joanna Chmist

joanna.chmist@up.poznan.pl

1 Department of Ecology and Environmental Protection, Faculty of Environmental Engineering and Spatial Management, Poznań University of Life Sciences, Wojska Polskiego 28 street, 60-637 Poznań, Poland

2 Institute of Plant Protection in Poznań, Węgorka 20 Street, 60-318 Poznań, Poland used worldwide (more than 1.8 billion kilograms per year) was recorded between 1960 and 1980 (Renault 2011). Currently, more than 1700 plant protection products, containing more than 220 active substances, are registered and used in Poland. However, due to the withdrawal from the market of some groups of pesticides in the 1970s, their excess was deposited in concrete wells. According to estimates of the Ministry of Environmental Protection, the total weight of pesticide waste in Poland may be as high as 60,000 tonnes. Data obtained by Ignatowicz (2007) show that the technical condition of these wells is very poor, leading to the emission of toxins and poisons to the natural environment. It has been shown that the concentration of several pesticides in water ecosystems is 100 times higher than that specified in the current regulations of the Minister of Health (2017) on the quality of water intended for human consumption (Niewiadowska et al. 2014).

The test pesticides were selected based on their wide use in Poland (or elsewhere) at present and in the past (Kucharski et al. 2011; Roszko et al. 2016). The study considered different groups of pesticides, such as herbicides, 
insecticides, and fungicides. The selected herbicide was a uracil substance called lenacil (3-cyclohexyl-1,5,6,7-tetrahydrocyclopentapyrimidine-2,4(3H)-dione), which in Poland and other countries is widely used in agriculture to control weeds. Lenacil is the active substance in many herbicide products. Lenacil is absorbed by the roots and translocated throughout the plant (Kucharski et al. 2011). The group of insecticides was represented by thiacloprid ((Z)-3-(6-chloro3-pyridylmethyl)-1,3-thiazolidin-2-ylidenecyanamide), dichlorodiphenyltrichloroethane (1,1,1-trichloro-2,2-bis(4chlorophenyl)ethane), and dichlorvos (2,2-dichlorovinyl dimethyl phosphate). Thiacloprid is an insecticide of the neonicotinoid class. The mechanism of its action is similar to that of other insecticides from the neonicotinoids group; it disturbs the insect's nervous system by stimulating nicotinic acetylcholine receptors (Schuld and Schmuck 2000). Dichlorodiphenyltrichloroethane, commonly known as DDT, is a compound that was developed as an organochlorine insecticide/acaricide. DDT has been shown to cause a number of adverse effects in animals. The side-effects of this insecticide mainly involve disorders of the reproductive, neurological, and immunological systems of animals (Bian et al. 2009). Dichlorvos, commonly known as DDVP, was widely used as an organophosphate insecticide/acaricide but was banned in December 2008. This compound gained notoriety due to its frequent occurrence in urban waterways. Despite its insecticidal purpose, its toxicity extends beyond insects. It is toxic to both invertebrates and vertebrates, including humans (Bolton-Warberg et al. 2007). Among the fungicides, tebuconazole was selected. Tebuconazole ((RS)-1-pchlorophenyl-4,4-dimethyl-3-(1H-1,2,4-triazol-1-ylmethyl) pentan-3-ol) is a very popular conazole fungicide (from the triazole fungicides group) used in agriculture to treat plant pathogenic fungi. It is classified as toxic to aquatic organisms. It may cause long-term adverse effects in the aquatic ecosystem (Yu et al. 2013). Tebuconazole is one of the most frequently detected pesticides in surface waters in Wielkopolska province, both lentic and lotic. In the years 2015-2017, tebuconazole was detected in $35.7 \%$, 25.5\%, and $52.8 \%$ (respectively) of all water samples collected and analysed at the Institute of Plant Protection NRI in Poznań, Poland. Tebuconazole, thiacloprid, and lenacil are still registered and widely used in Polish agriculture (Roszko et al. 2016).

Increasing the application of pesticides requires caution in use and more studies on their impact on ecosystems (Falconer 2006; Kazi et al. 2009). One of the groups of organisms that are at the greatest risk from the adverse effects of pesticides is the bivalves-one of the most varied and species-rich groups of aquatic creatures (Oehlmann and Schulte-Oehlmann 2003; Bouilly et al. 2007). Bivalves play an important ecological role in various ecosystems, both freshwater and marine, mainly because they are efficient water filters. In addition, they are good indicators of environmental quality, especially for rivers and lakes (Donrovich et al. 2017). Due to their relatively sedentary lifestyle, they have limited abilities to escape in the event of threats (Cossu et al. 2000).

The effects of pesticides on bivalves have already been studied in various types of ecosystems, although the number of publications is still very limited (Galloway et al. 2002; Greco et al. 2010). This study provided a unique outlook on the impact of pesticides on bivalves. Using original laboratory equipment, highly precise monitoring of various elements of the bivalves' behaviour was possible. The testing of five types of pesticides of particular significance for the environment aligns with the challenges faced in contemporary agricultural ecosystems. We hypothesized that pesticide contamination has a significant impact on bivalves, reflected by various behavioural reactions, such as activity time, shell opening rate, and shell opening level.

\section{Materials and Methods}

\section{Tested Pesticides}

This study focused on toxic pesticides which pose a serious risk to the environment. According to the Globally Harmonized System of Classification and Labelling of Chemicals (GHS), all of them are classified as H400: very toxic to aquatic life, or as H410: very toxic to aquatic life with long lasting effects (Table 1).

In the experiments, each pesticide compound was introduced in a nominal concentration of $10 \mu \mathrm{g} \mathrm{L}^{-1}$. The pesticide concentration was detected in separate experiments with the insecticides, fungicide, and herbicide. A method of solid phase extraction was used for analysis of the changes in concentration (instrumental analysis using liquid chromatography with LC-MS/MS mass detection). The analysis was performed in duplicate, and the results from the replicates were averaged. During the experiment, water samples were analysed three times ( $24 \mathrm{~h}, 72 \mathrm{~h}$, and $120 \mathrm{~h}$ after exposure).

\section{Unio tumidus Maintenance and Exposure}

Freshwater Unio tumidus bivalves were collected from a water reservoir in Wielkopolska province, Poland, in 2017 and 2018. All of the bivalves were estimated to be adults with ages ranging from 6 to 9 years (Jakubik and Lewandowski 2016) and were uniform in size $(N=40,6 \pm 1-\mathrm{cm}$ length and $3.5 \pm 0.5-\mathrm{cm}$ width). All selected bivalves were transported in special tanks courtesy of the Department of Ecology and Environmental Protection laboratory at Poznań University of Life Sciences. They were placed in an aquarium $(125 \mathrm{~L})$ with continuous aeration and with access to 
Table 1 Characteristics of the five pesticides tested according to according to the Globally Harmonized System of Classification and Labelling of Chemicals (GHS)

\begin{tabular}{|c|c|c|c|c|}
\hline Pesticide & $\begin{array}{l}\text { Agro- } \\
\text { chemical } \\
\text { category }\end{array}$ & Molecular formula & Hazards identification (GHS) & Reference \\
\hline Lenacil & Herbicide & $\mathrm{C}_{13} \mathrm{H}_{18} \mathrm{~N}_{2} \mathrm{O}_{2}$ & $\begin{array}{l}\text { H351: Suspected of causing cancer } \\
\text { H400: Very toxic to aquatic life } \\
\text { H410: Very toxic to aquatic life with long-lasting } \\
\text { effects }\end{array}$ & European Chemicals Agency (ECHA) \\
\hline DDT & Insecticide & $\mathrm{C}_{14} \mathrm{H}_{9} \mathrm{C}_{15}$ & $\begin{array}{l}\text { H301 + H311: Toxic if swallowed or in contact with } \\
\text { skin } \\
\text { H301: Toxic if swallowed } \\
\text { H311: Toxic in contact with skin } \\
\text { H351: Suspected of causing cancer } \\
\text { H372: Causes damage to organs through prolonged } \\
\text { or repeated exposure } \\
\text { H400: Very toxic to aquatic life } \\
\text { H410: Very toxic to aquatic life with long-lasting } \\
\text { effects }\end{array}$ & European Chemicals Agency (ECHA) \\
\hline Thiacloprid & Insecticide & $\mathrm{C}_{10} \mathrm{H}_{9} \mathrm{ClN}_{4} \mathrm{~S}$ & $\begin{array}{l}\text { H301: Toxic if swallowed } \\
\text { H332: Harmful if inhaled } \\
\text { H336: May cause drowsiness or dizziness } \\
\text { H351: Suspected of causing cancer } \\
\text { H360FD: May damage fertility; May damage the } \\
\text { unborn child } \\
\text { H400: Very toxic to aquatic life } \\
\text { H410: Very toxic to aquatic life with long-lasting } \\
\text { effects }\end{array}$ & European Chemicals Agency (ECHA) \\
\hline DDVP & Insecticide & $\mathrm{C}_{4} \mathrm{H}_{7} \mathrm{Cl}_{2} \mathrm{O}_{4} \mathrm{P}$ & $\begin{array}{l}\text { H301: Toxic if swallowed } \\
\text { H311: Toxic in contact with skin } \\
\text { H317: May cause an allergic skin reaction } \\
\text { H330: Fatal if inhaled } \\
\text { H400: Very toxic to aquatic life }\end{array}$ & EU REGULATION (EC) No 1272/2008 \\
\hline Tebuconazole & Fungicide & $\mathrm{C}_{16} \mathrm{H}_{22} \mathrm{ClN}_{3} \mathrm{O}$ & $\begin{array}{l}\text { H320: Causes eye irritation } \\
\text { H330: Fatal if inhaled } \\
\text { H351: Suspected of causing cancer } \\
\text { H361: Suspected of damaging fertility or the unborn } \\
\text { child } \\
\text { H371: May cause damage to organs } \\
\text { H373: Causes damage to organs through prolonged } \\
\text { or repeated exposure } \\
\text { H400: Very toxic to aquatic life } \\
\text { H410: Very toxic to aquatic life with long-lasting } \\
\text { effects }\end{array}$ & EU REGULATION (EC) No 1272/2008 \\
\hline
\end{tabular}

food. All bivalves were left for approximately 3 weeks to reduce the stress associated with transport. Fine sand was placed at the bottom of the tank. During the experiment, the water $\mathrm{pH}$ ranged between 7.6 and 8.4 at a temperature of between 10 and $12{ }^{\circ} \mathrm{C}$, and dissolved oxygen (DO) was maintained at a level between 7.8 and $8.1 \mathrm{mg} \mathrm{L}^{-1}$. No mortality was observed during the acclimatization period.
Stock solutions of the test chemicals were prepared in $10 \mu \mathrm{g} \mathrm{L}^{-1}$ concentrations. The selected organisms were randomly divided into five groups of eight individuals. During both the control and exposure periods the bivalves were not fed. The test concentrations were fixed for each test substance based on reference literature (Ignatowicz 2007). The bivalves were exposed for $168 \mathrm{~h}$ (including the day of introduction of the substance). Behavioural observations were 
made for every second, and the median for each day was taken for analysis. For each stock solution, the characteristic behaviour of the bivalves before and after the introduction of the pesticide was noted. The bivalves spent 20 days in the system: 9 days for acclimation, 5 days to establish behaviour under control conditions, and 7 days of exposure to the pesticide. Due to the toxicity of the pesticides, some bivalves died. They were removed from the system to maintain a suitable environment.

\section{Construction of the Behaviour Monitoring System}

The standard Biological Early Warning System was used in this study; its construction is shown in Fig. 1. The changes in shell movements were measured by a Hall sensor (a transducer for magnetic field strength) with a small ferrite magnet (diameter $8 \mathrm{~mm}$ ) connected to it. All shell movements were measured continuously and recorded by software.

The system was based on magnetic field changes. Hall sensors were selected as magnetic field transducers due to their small physical dimensions and high sensitivity (Prauzner and Ptak 2014). The magnetic field changes caused by movement of the magnet are converted to the corresponding percentage level of shell opening (Fig. 2). The minimum and maximum range is established for each individual during calibration, in accordance with the relationship shown in Fig. 2.

For each experiment, 8 bivalves were placed in an aquarium $(150 \times 25 \times 25 \mathrm{~cm})$ filled with aerated commercially distributed drinkable spring water (water parameters: $\mathrm{HCO}_{3}{ }^{-} 134.20 \mathrm{mg} \mathrm{L}^{-1}, \mathrm{SO}_{4}{ }^{2-} 69.54 \mathrm{mg} \mathrm{L}^{-1}$, $\mathrm{Cl}^{-} 18.00 \mathrm{mg} \mathrm{L}^{-1}, \mathrm{~F}^{-} 0.16 \mathrm{mg} \mathrm{L}^{-1}, \mathrm{Ca}^{2+} 60.12 \mathrm{mg} \mathrm{L}^{-1}$, $\mathrm{Mg}^{2+} 13.37 \mathrm{mg} \mathrm{L}^{-1}, \mathrm{Na}^{+} 5.00 \mathrm{mg} \mathrm{L}^{-1}, \mathrm{~K}^{+} 0.75 \mathrm{mg} \mathrm{L}^{-1}$, temperature $14-16^{\circ} \mathrm{C}$, DO $7.8-9.1 \mathrm{mg} \mathrm{L}^{-1}$, $\mathrm{pH} 8.0-8.4$ ), circulated using an air pump (Fig. 1). Changes in valve movements were monitored continuously.

Changes in the shell opening level of the exposed bivalves, measured in real time, were compared with the control period. Five days in clean water at a temperature of 10 to $12 \pm 1{ }^{\circ} \mathrm{C}$ was taken to represent control conditions. In the case of shell opening rate and activity time, before the introduction of the pesticides, the behaviour was very stable and the data were analysed in a block, without any division into individual days. Approximately 86,400 behaviour change records were collected each day.

\section{Statistics}

Statistical differences between the control and the treatment period were tested using the Kruskal-Wallis ANOVA by rank test $(p<0.05)$. Tests for data normality were performed previously.

\section{Results}

\section{Shell Opening Level}

The application of pesticides induced quite a limited reaction in the shell opening level of the bivalves. The average
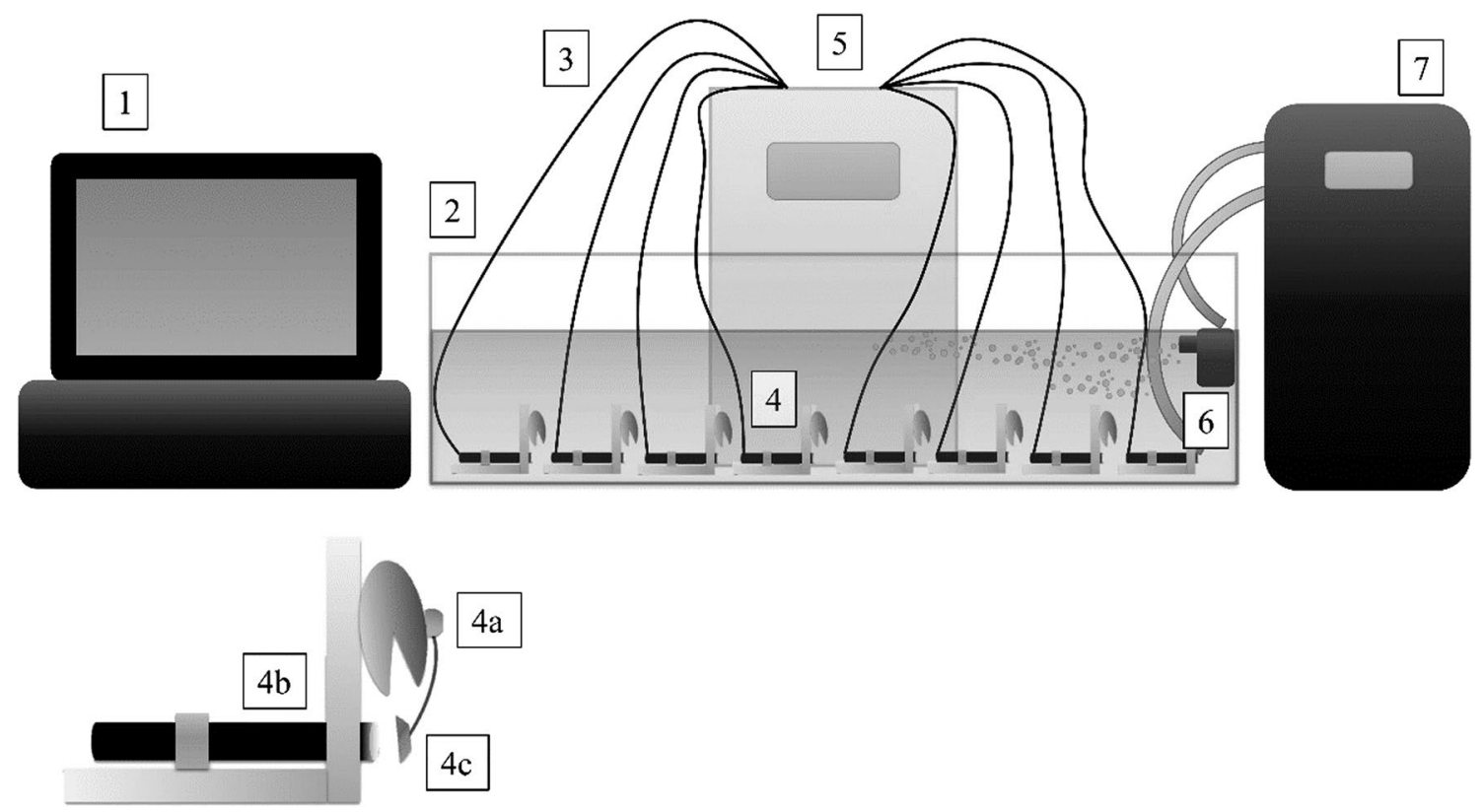

Fig. 1 Construction of biological early warning system: (1) computer with dedicated software; (2) aquarium; (3) connection of sensors with the controller; (4) organisms connected to the system; (4a) bivalve; (4b) hall sensor; (4c) magnet; (5) controller; (6) air pump; (7) aquarium chiller 


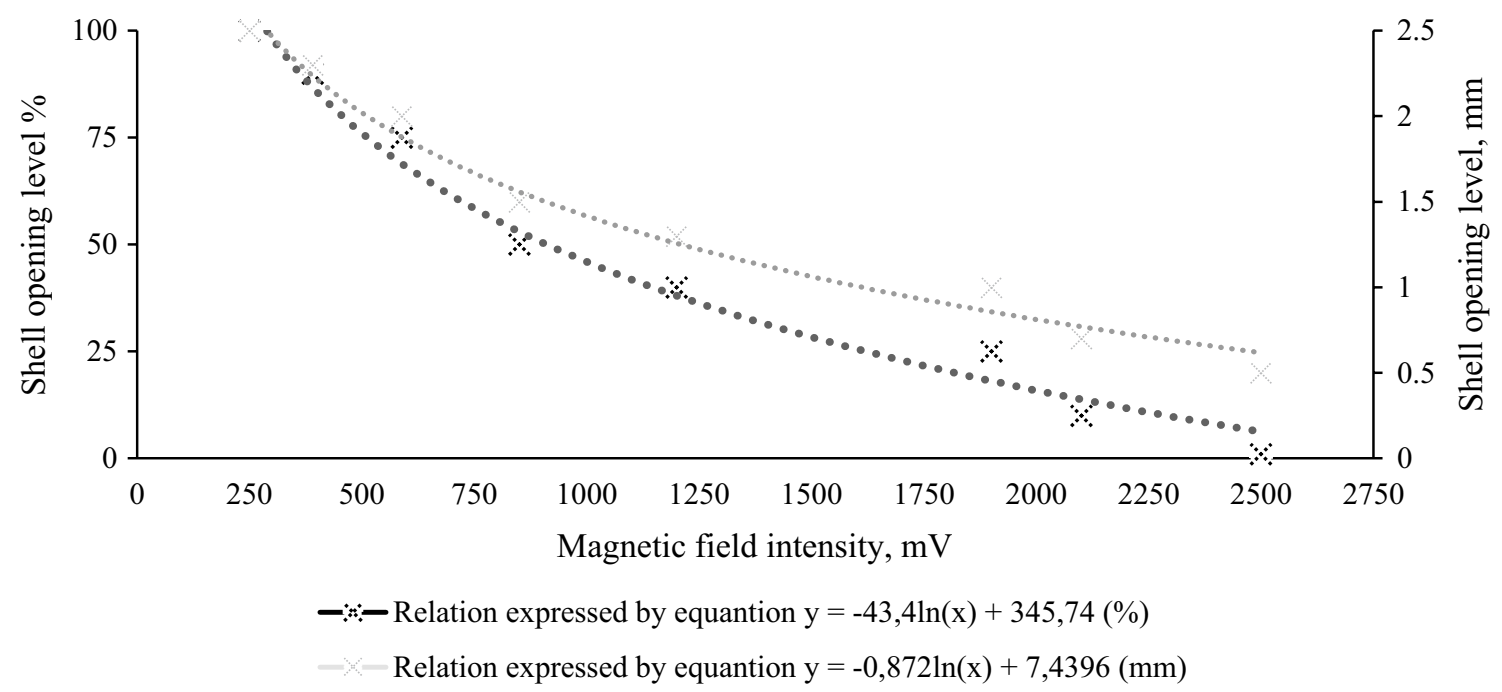

Fig. 2 Relationship between the magnetic field intensity and the shell opening level

level (daily median) of shell opening for the set of eight tested bivalves showed fluctuations after a decrease during the first day after exposure (lenacil, thiacloprid, tebuconazole) or after an initial decrease following treatment (DDT and DDVP). The strongest stress reaction was observed in the case of DDVP treatment, where significant differences were detected between the control and treatment periods ( $p>0.0001, H=54.80)$. After 8 days, the shell opening level increased to $100 \%$. This was the result of total muscle paralysis, which led to a lethal state. All eight bivalves died during the experiment (Fig. 3c).

\section{Shell Opening Rate}

The application of pesticides caused a clear change in the shell opening rate. During the control period, in each group, the shell opening rate ranged from 0.006 to $0.009 \mathrm{~cm} \mathrm{~s}^{-1}$. The difference results from the greater activity of some bivalves. In the absence of an additional stress factor, the increase in this parameter indicates an increased frequency of shift from activity to rest and vice versa.

The most apparent increase in shell opening rate was caused by lenacil treatment (median increase by $0.03 \mathrm{~cm} \mathrm{~s}^{-1}$ ) (Fig. 4). A significant reaction was also detected as a result of treatment with tebuconazole $\left(0.001 \mathrm{~cm} \mathrm{~s}^{-1}\right)$ and with two of the tested insecticides: DDVP (0.002) and thiacloprid (0.002). The impact of all of these pesticides was highly significant according to Kruskal-Wallis ANOVA rank tests with $p<0.001$. The impact of DDT on the shell opening rate was very limited, and no significance was confirmed $(p=0.189)$.

\section{Activity Time}

The daily activity time during the control period ranged from 10 to $17 \mathrm{~h}$. The differences result from the life cycles of individual specimens.

Pesticide application induced an apparent reaction in the activity time of the bivalves in most cases. The most apparent reaction occurred in the case of DDVP. During the control period, the median activity time was $12 \pm 3 \mathrm{~h}$; after exposure it increased to $22 \mathrm{~h}$. A very noticeable impact also was detected in the case of tebuconazole application. Here, during the control period, the median activity time was $17 \pm 3 \mathrm{~h}$, and after exposure, it decreased to $8 \mathrm{~h}$ (Fig. 5). Kruskal-Wallis ANOVA proved the high level of significance (rank tests) of daily activity time between the control and treatment period both for DDVP $(p>0.001, H=46.23)$ and tebuconazole ( $p>0.001, H=37.61)$. A significant impact of DDT application was observed ( $p=0.034, H=18.49$ ). In the case of lenacil and thiacloprid, a decrease in daily activity also was observed, but the differences between the control and treatment periods were not significant.

\section{Changes of Pesticides Concentration}

During separate experiments, the variability of pesticide concentration was estimated. The concentration level decreased during the observation period (Fig. 6). The decrease in concentration was generally small, although some differences were observed between substances. The largest decrease in the residue concentration was recorded in case of the tested insecticides: between 24 and 120 h of exposure, the concentration decreased by $34.4 \%$, compared with a decrease of $21.4 \%$ for the fungicide and only $11.2 \%$ for the herbicide (Fig. 6). 
Fig. 3 Changes in shell opening level before and during treatment period. a Shell opening level for Lenacil, b shell opening level for DDT, $\mathbf{c}$ shell opening level for DDVP, $\mathbf{d}$ shell opening level for Thiacloprid, e shell opening level for Tebuconazole

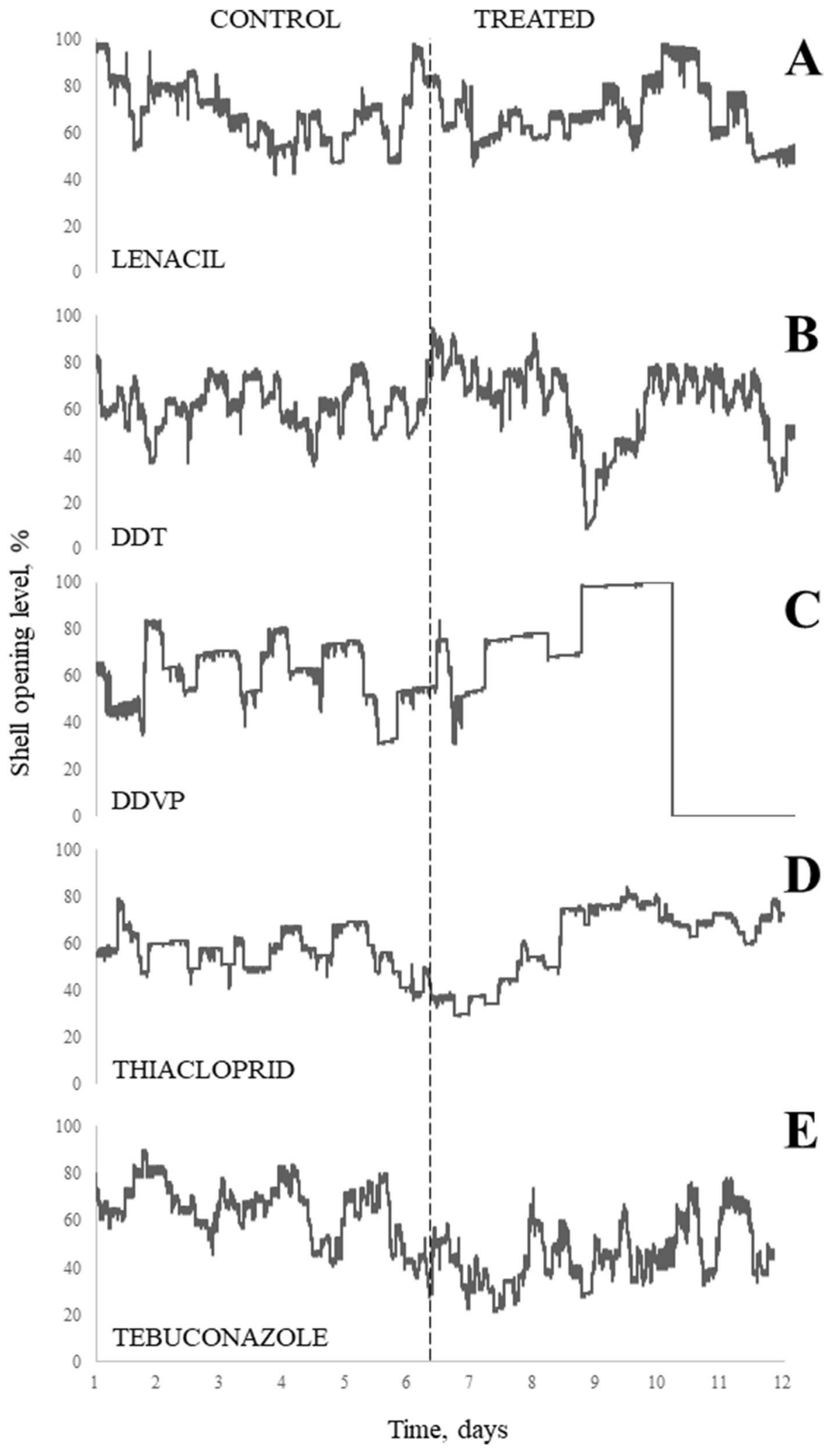


Fig. 4 Median shell opening rate before and after exposure to pesticides. Control period (dark colour); treated period (light colour). Significant differences are marked by $*$ where $* 0.05<p<0.01$,

$* * 0.01 \leq p<0.001$,

$* * * p \leq 0.001$

Fig. 5 Median activity time before and after exposure to pesticides. Control period (dark colour); treated period (light colour). Significant differences are marked by $*$ where $* 0.05<p<0.01$, $* * 0.01 \leq p<0.001$,

$* * * p \leq 0.001$
Fig. 6 Pesticide concentration change during the experiment
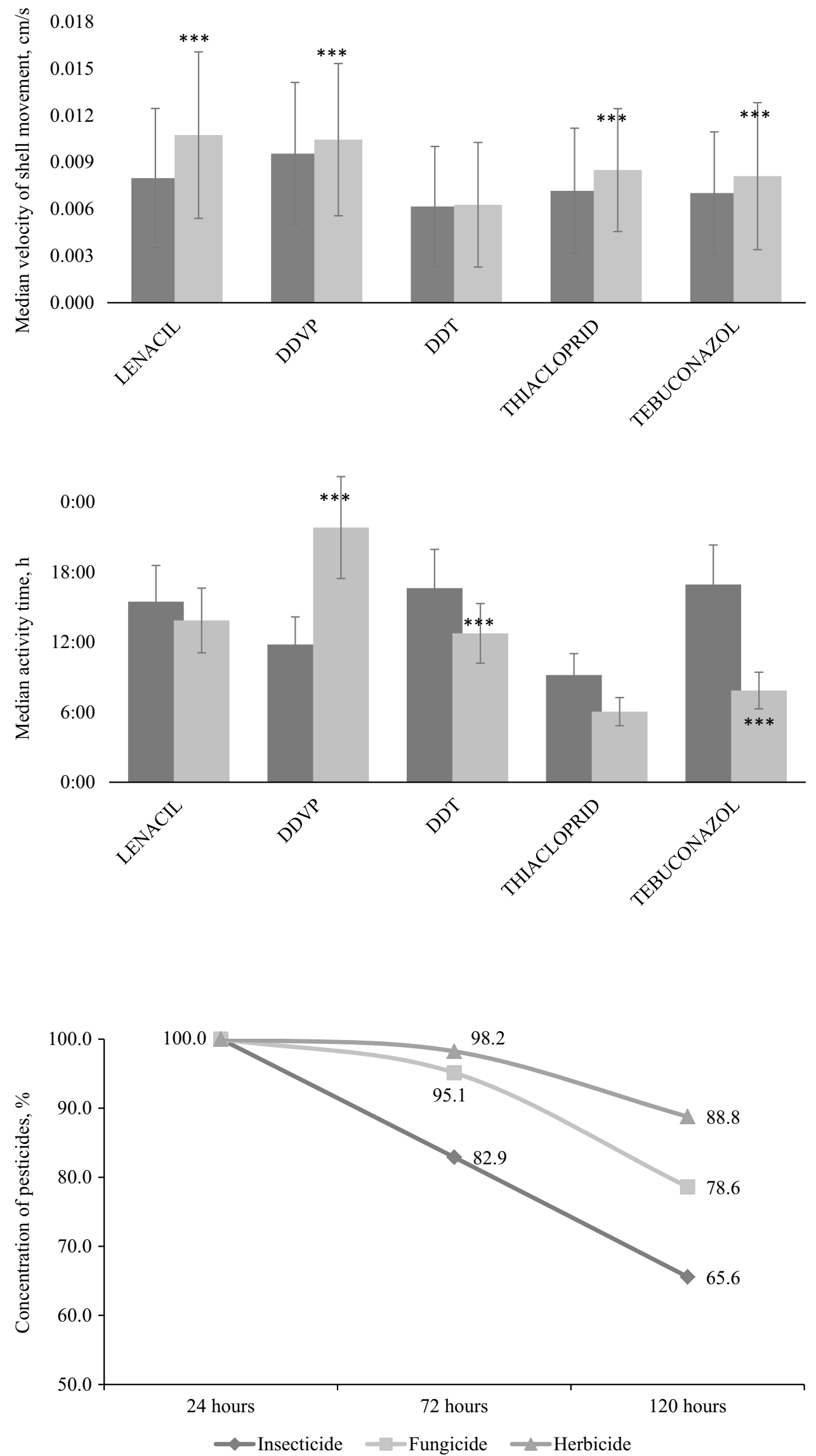


\section{Discussion}

The results of the research show that the toxic effects of various pesticides on mussels is differentiated in terms of their impact on behaviour, including shell opening level, activity time, and shell opening rate, as well as the rapid onset of death. This study provides scientific evidence regarding the biological effects of pesticides on freshwater bivalves that are native to Poland. As reported by Renault (2011), the problem is serious, because contamination can have a negative impact on entire trophic chains of aquatic ecosystems.

Our analyses showed that pesticide contamination affects shell opening level to a small extent. Exposure to lenacil, DDT, thiacloprid, and tebuconazole has an insignificant effect on the reaction of $U$. tumidus ( $p>0.05$ ). Only bivalves exposed to DDVP showed significant change in shell opening level, which resulted from the death of all tested organisms. Therefore, the experiments demonstrated that even a high concentration of pesticides, under short-term exposure, has no influence on the shell opening level of the European unionoid $U$. tumidus. Bivalves usually keep their shells open more than $70 \%$ of the time (for oxygen and food intake). The total closure of shells occurs only if there is significant contamination of the water, because it involves significant energy losses (Kramer and Foekema 2001).

The study has shown that pesticide application affects shell opening rates. Exposure to lenacil, DDVP, thiacloprid, and tebuconazole had a highly significant effect on U. tumi$d u s$ shell movement $(p<0.05)$. Only DDT treatment did not induce any behavioural reactions. The apparent change of shell opening rate under pesticide contamination has been reported in several previous studies (Ayad et al. 2011; Hartmann et al. 2016), but this pattern has a limited application in biomonitoring. Most biological warning systems are still based solely on the change in shell opening level (Bae and Park 2014). The introduction of shell opening rates into existing systems may increase the effectiveness of pesticide detection.

Although mortality during our short-term experiments was detected only in the case of DDVP contamination, all of the analysed substances have been demonstrated to have harmful effects in previous studies. Liess and Ohe (2005) reported that herbicides from surface runoff can be a cause of acute mortality in benthic invertebrates even at low concentrations. They also recorded a significant reduction in invertebrate taxonomic richness and abundance during spring, when the highest pesticide concentrations were found. Binelli et al. (2001) showed that DDTs have endocrine-disrupting effects in Dreissena polymorpha species. Oocyte degeneration may contribute to reductions in the population of individual species. In addition, most molluscs manifest a high accumulation of DDT in soft tissues.
Binelli and Provini (2003) reported total DDT levels exceeding $3.12 \mu \mathrm{g} \mathrm{g}^{-1}$ in the soft tissues of Dreissena polymorpha. Moreover, DDT is still recorded in Poland, in both surface water and sediments. Reindl and Bolałek (2018) observed that in sediments of the Vistula Lagoon, concentrations of DDT lay within a range of $22.7-405.7 \mathrm{ng} \mathrm{kg}^{-1} \mathrm{dw}$. Several studies have investigated the effects of DDVP on living organisms, and in many cases this substance adversely affected bivalves. Relaxation of the adductor muscle of two bivalve species was reported by Le Bris et al. (1995). During $42 \mathrm{~h}$ of exposure to dichlorvos in concentrations of 0.1 and $1 \mu \mathrm{g} \mathrm{L}^{-1}$, bivalves behaved as if paralysed. Also, BoltonWarberg et al. (2007) identified specific bivalve behaviour during a 96-h toxicity test. They observed relaxed adductor muscles in two species of molluscs subject to two DDVP concentrations (10 and $100 \mu \mathrm{g} \mathrm{L}^{-1}$ ). In the present study, we also observed similar bivalve behaviour under a DDVP concentration of $10 \mu \mathrm{g} \mathrm{L}^{-1}$. Based on the observations of Bolton-Warberg et al. this paralysis is caused by muscle fatigue. This may be a result of prolonged shrinkage of the muscles, associated with DDVP exposure. Neither Le Bris et al. (1995) nor Bolton-Warberg et al. (2007) observed any deaths.

In our study, all of the lethal cases were recorded after 7 days of exposure. Beketov and Liess (2008) observed delayed toxic effects occurring after exposure to thiacloprid. They admit that even with a 24-h exposure (at concentration $85 \mu \mathrm{g} \mathrm{L}^{-1}$, lower than the LC50 for Daphnia magna) death may be delayed. An increase in mortality was observed in several species 4-12 days after exposure. In our study, no fatalities were observed. At a concentration of $10 \mu \mathrm{g} \mathrm{L}^{-1}$, thiacloprid caused only an insignificant increase in the velocity of shell movement. Moreover, thiacloprid is included on the Watch List of contaminants of emerging concern (CECs) for European Union monitoring of surface water (launched in Decision 2015/495) (Sousa et al. 2019). Additionally, the effect of tebuconazole on freshwater invertebrates has been studied mainly for Daphnia magna, Danio rerio, Gammarus fossarum, etc. (Sancho et al. 2009; Zubrod et al. 2010; Andreu-Sánchez et al. 2012). However, Sancho et al. (2009) showed that the daily activity of daphnia decreased as tebuconazole concentration increased. The differences were observed after $96-120 \mathrm{~h}$ of exposure to $0.52 \mu \mathrm{g} \mathrm{L}^{-1}$ and higher concentrations of tebuconazole. In our study, we also observed reduced activity at a concentration of $10 \mu \mathrm{g} \mathrm{L}^{-1}$. Gammarids also showed significant reductions in activity, feeding, assimilation, and growth (Zubrod et al. 2010). The data suggest that tebuconazole is moderately toxic to invertebrates. However, it seriously impairs metabolic functions (Sancho et al. 2009; Andreu-Sánchez et al. 2012).

A decrease in the activity time, and thus the time of water filtration, was observed after exposure to lenacil, DDT, thiacloprid, and tebuconazole. However, statistically significant 
differences were demonstrated only for DDT and tebuconazole $(p<0.05)$. In the case of DDVP, the increase in activity resulted from muscle paralysis and thus the inability to close the shell. Even a small decrease in activity during the day reduces the amount of water filtered by the bivalves.

The great variability in terms of bivalves' response depends on the duration of exposure, pesticide concentration or test species (Crestani et al. 2007; Modesto and Martinez 2010). However, Greco et al. (2010) concluded that other factors too, such as increased temperature, may modify bivalves' response to pesticides. Aquatic creatures may be exposed to numerous variables. Abiotic factors (i.e., other pollutants, different temperatures, salinities, quantities of dissolved oxygen, and changes in $\mathrm{pH}$ ) may accelerate the negative effect of pesticides (Broomhall 2002; Rohr et al. 2011).

Today, the tested pesticides are regularly detected and are recognised as a serious environmental threat (Beketov et al. 2013). According to the Water Framework Directive (European Commission 2000), all of the tested pesticides are regarded as toxic, and their active substances are included as priority substances (European Commission 2000). According to the Globally Harmonized System of Classification and Labelling of Chemicals (GHS), these pesticides are classified as H400: very toxic to aquatic life, or as H410: very toxic to aquatic life with long-lasting effects. All of them are regularly found in Poland and other European countries.

Two of the tested pesticides are not currently used (DDT and DDVP); however, their impact on the environment is still high, and the resulting risks are closely monitored. According to Directive 2013/39/EU, they are constant causes of mutagenic and carcinogenic fatal damage. Due to their particular ecological durability, both of them are still frequently detected in Poland (Kaczyński et al. 2017) and other parts of Europe (Oliveira et al. 2015; Quadroni and Bettinetti 2017; Lan et al. 2019), as well as outside Europe (Chen et al. 2016).

During the experiments, the nominal concentration $10 \mu \mathrm{g} \mathrm{L}{ }^{-1}$ was used for each pesticide tested. Based on current European regulations, pesticide concentration in drinking water should not exceed $0.1 \mathrm{mg} \mathrm{L}^{-1}$ for a single pesticide (Council Directive 98/83/EC). However, in natural ecosystems the level of pesticides may be as much as 100 times higher (Satyavani et al. 2011).

Despite the fact that the impact of pesticides on ecosystems is under regular observation with the use of a wide range of scientific techniques, the use of bivalves has been shown to have considerable potential for water-quality monitoring. Based on behavioural observations, we have obtained a clear bioindicative response to water pollution by different types of pesticides. The investigations addressing the ecotoxicological effects of fungicides, herbicides, and insecticides on aquatic invertebrates seem to be adequate for a reliable assessment of adverse effects in freshwater ecosystems. However, further detailed studies are needed to utilize the bioindicative signals generated by bivalves under the stress of pollution and better understand the complex interactions between pesticides and the freshwater environment.

Acknowledgements The authors thank the company PROTE for providing us with the Biological Early Warning System (SYMBIO system) used in this study. They also thank the native speaker John Catlow for his support as well as two anonymous referees and the editor for providing constructive and valuable suggestions on earlier versions of the manuscript. Part of this study, regarding the bivalves' behavioural reactions, was funded by the Ministry of Science and Higher Education ("Diamond Grant" DI2015 007345, Natural Sciences).

Open Access This article is distributed under the terms of the Creative Commons Attribution 4.0 International License (http://creativeco mmons.org/licenses/by/4.0/), which permits unrestricted use, distribution, and reproduction in any medium, provided you give appropriate credit to the original author(s) and the source, provide a link to the Creative Commons license, and indicate if changes were made.

\section{References}

Andreu-Sánchez O, Paraíba LC, Jonsson CM, Carrasco JM (2012) Acute toxicity and bioconcentration of fungicide tebuconazole in zebrafish (Danio rerio). Environ Toxicol 27(2):109-116. https:// doi.org/10.1002/tox.20618

Ayad MA, Fdil MA, Mouabad A (2011) Effects of cypermethrin (pyrethroid insecticide) on the valve activity behavior, byssal thread formation, and survival in air of the marine mussel Mytilus galloprovincialis. Arch Environ Contam Toxicol 60(3):462-470

Bae MJ, Park YS (2014) Biological early warning system based on the responses of aquatic organisms to disturbances: a review. Sci Total Environ 466:635-649

Beketov MA, Liess M (2008) Acute and delayed effects of the neonicotinoid insecticide thiacloprid on seven freshwater arthropods. Environ Toxicol Chem 27(2):461-470. https://doi. org/10.1897/07-322R.1

Beketov MA, Kefford BJ, Schäfer RB, Liess M (2013) Pesticides reduce regional biodiversity of stream invertebrates. Proc Natl Acad Sci 110(27):11039-11043. https://doi.org/10.1073/ pnas. 1305618110

Bian X, Liu H, Gan J, Li R, Yang J (2009) HCH and DDT residues in bivalves Anodonta woodiana from the Taihu Lake. China. Arch Environ Contam Toxicol 56(1):67-76. https://doi.org/10.1007/ s00244-008-9173-y

Binelli A, Provini A (2003) DDT is still a problem in developed countries: the heavy pollution of Lake Maggiore. Chemosphere 52(4):717-723. https://doi.org/10.1016/S0045-6535(03)00188-7

Binelli A, Bacchetta R, Vailati G, Galassi S, Provini A (2001) DDT contamination in Lake Maggiore (N. Italy) and effects on zebra mussel spawning. Chemosphere 45(4-5):409-415. https://doi. org/10.1016/s0045-6535(01)00048-0

Bolton-Warberg M, Coen LD, Weinstein JE (2007) Acute toxicity and acetylcholinesterase inhibition in grass shrimp (Palaemonetes pugio) and oysters (Crassostrea virginica) exposed to the organophosphate dichlorvos: laboratory and field studies. Arch Environ Contam Toxicol 52(2):207-216. https://doi.org/10.1007/ s00244-005-0325-z

Bouilly K, Bonnard M, Gagnaire B, Renault T, Lapègue S (2007) Impact of diuron on aneuploidy and hemocyte parameters in 
Pacific oyster, Crassostrea gigas. Arch Environ Contam Toxicol 52(1):58-63. https://doi.org/10.1007/s00244-005-0256-8

Broomhall S (2002) The effects of endosulfan and variable water temperature on survivorship and subsequent vulnerability to predation in Litoria citropa tadpoles. Aquat Toxicol 61(3-4):243-250. https ://doi.org/10.1016/S0166-445X(02)00061-9

Chen H, Zhu J, Li Z, Chen A, Zhang Q (2016) The occurrence and risk assessment of five organophosphorus pesticides in river water from Shangyu, China. Environ Monit Assess 188(11):614. https ://doi.org/10.1007/s10661-016-5612-9

Cossu C, Doyotte A, Babut M, Exinger A, Vasseur P (2000) Antioxidant biomarkers in freshwater bivalves, Unio tumidus, in response to different contamination profiles of aquatic sediments. Ecotoxicol Environ Saf 45(2):106-121. https://doi.org/10.1006/ eesa.1999.1842

Council Directive 98/83/EC of 3 November 1998 on the quality of water intended for human consumption

Crestani M, Menezes C, Glusczak L, dos Santos Miron D, Spanevello R, Silveira A, Gonçalves FF, Zanella R, Loro VL (2007) Effect of clomazone herbicide on biochemical and histological aspects of silver catfish (Rhamdia quelen) and recovery pattern. Chemosphere 67(11):2305-2311. https://doi.org/10.1016/j.chemospher e.2006.09.070

Cruzeiro C, Pardal MÂ, Rodrigues-Oliveira N, Castro LFC, Rocha E, Rocha MJ (2016) Multi-matrix quantification and risk assessment of pesticides in the longest river of the Iberian peninsula. Sci Total Environ 572:263-272. https://doi.org/10.1016/j.scito tenv.2016.07.203

Donrovich SW, Douda K, Plechingerová V, Rylková K, Horký P, Slavík O, Liu HZ, Reichard M, Lopes-Lima M, Sousa R (2017) Invasive Chinese pond mussel Sinanodonta woodiana threatens native mussel reproduction by inducing cross-resistance of host fish. Aquat Conserv Mar Freshw Ecosyst. https://doi. org/10.1002/aqc. 2759

Edwards CA (ed) (2013) Environmental pollution by pesticides, vol 3. Springer, Berlin

European Commission (2000) Directive 2000/60/EC of the European Parliament and of the Council-Establishing a Framework for Community Action in the Field of Water Policy

Falconer IR (2006) Are endocrine disrupting compounds a health risk in drinking water? Int J Environ Res Public Health 3(2):180-184. https://doi.org/10.3390/ijerph2006030020

Galloway TS, Sanger RC, Smith KL, Fillmann G, Readman JW, Ford TE, Depledge MH (2002) Rapid assessment of marine pollution using multiple biomarkers and chemical immunoassays. Environ Sci Technol 36(10):2219-2226. https://doi.org/10.1021/es010 $300 \mathrm{w}$

Greco L, Pellerin J, Capri E, Garnerot F, Louis S, Fournier M, Sacchi A, Fusi M, Lapointe D, Couture P (2010) Physiological effects of temperature and a herbicide mixture on the soft-shell clam Mya arenaria (Mollusca, Bivalvia). Chemosphere 81(6):692700. https://doi.org/10.1002/etc.359

Hartmann JT, Beggel S, Auerswald K, Stoeckle BC, Geist J (2016) Establishing mussel behavior as a biomarker in ecotoxicology. Aquat Toxicol 170:279-288. https://doi.org/10.1016/j.aquat ox.2015.06.014

Ignatowicz K (2007) Określenie migracji pozostałości pestycydów i metali ciężkich z mogilników do wód naturalnych. Rocznik Ochrony Środowiska 9:281-292

Jakubik B, Lewandowski K (2016) Co można odczytać z muszli mięczaka? Kosmos 3(65):455-462

Kaczyński P, Łozowicka B, Perkowski M, Szabuńko J (2017) Multiclass pesticide residue analysis in fish muscle and liver on one-step extraction-cleanup strategy coupled with liquid chromatography tandem mass spectrometry. Ecotoxicol Environ Saf 138:179-189. https://doi.org/10.1016/j.ecoenv.2016.12.040
Kazi TG, Arain MB, Jamali MK, Jalbani N, Afridi HI, Sarfraz RA, Baig JA, Shah AQ (2009) Assessment of water quality of polluted lake using multivariate statistical techniques: a case study. Ecotoxicol Environ Saf 72(2):301-309. https://doi. org/10.1016/j.ecoenv.2008.02.024

Kramer KJM, Foekema EM (2001) The "Musselmonitor" as biological early warning system. In: Butterworth FM, Gunatilaka A, Gonsebatt ME (eds) Biomonitors and biomarkers as indicators of environmental change 2: a handbook. Springer, New York, pp 59-87

Kucharski M, Sadowski J, Wujek B, Trajdos J (2011) Influence of adjuvants addition on lenacil residues in plant and soil. Polish $\mathrm{J}$ Agron 5:39-42

Lan J, Jia J, Liu A, Yu Z, Zhao Z (2019) Pollution levels of banned and non-banned pesticides in surface sediments from the East China Sea. Mar Pollut Bull 139:332-338. https://doi.org/10.1016/j. marpolbul.2019.01.006

Le Bris H, Maffart P, Bocquené G, Buchet V, Galgani F, Blanc G (1995) Laboratory study on the effect of dichlorvos on two commercial bivalves. Aquaculture 138:139-144. https://doi. org/10.1016/0044-8486(95)01087-4

Liess M, Ohe PCVD (2005) Analyzing effects of pesticides on invertebrate communities in streams. Environ Toxicol Chem 24(4):954965. https://doi.org/10.1897/03-652.1

Modesto KA, Martinez CB (2010) Roundup ${ }^{\circledR}$ causes oxidative stress in liver and inhibits acetylcholinesterase in muscle and brain of the fish Prochilodus lineatus. Chemosphere 78(3):294-299. https ://doi.org/10.1016/j.chemosphere.2009.10.047

Niewiadowska A, Kiljanek T, Semeniuk S, Żmudzki J (2014) Contamination of omnivorous freshwater fish species and sediments by chlorinated hydrocarbons in Poland. Bull Vet Inst Pulawy 58(3):405-411. https://doi.org/10.2478/bvip-2014-0063

Nowell LH, Norman JE, Moran PW, Martin JD, Stone WW (2014) Pesticide toxicity index-a tool for assessing potential toxicity of pesticide mixtures to freshwater aquatic organisms. Sci Total Environ 476:144-157. https://doi.org/10.1016/j.scitotenv.2013.12.088

Oehlmann J, Schulte-Oehlmann U (2003) Molluscs as bioindicators. In: Markert BA, Breure AM, Zechmeister HG (eds) Trace metals and other contaminants in the environment, vol 6. Elsevier, Amsterdam, pp 577-635

Oliveira FA, Reis LP, Soto-Blanco B, Melo MM (2015) Pesticides residues in the Prochilodus costatus (Valenciennes, 1850) fish caught in the São Francisco River, Brazil. J Environ Sci Health B 50(6):398-405. https://doi.org/10.1080/03601234.2015.1011946

Pathiratne A, Kroon FJ (2016) Using species sensitivity distribution approach to assess the risks of commonly detected agricultural pesticides to Australia's tropical freshwater ecosystems. Environ Toxicol Chem 35(2):419-428. https://doi.org/10.1002/etc.3199

Prauzner T, Ptak P (2014) Analiza parametrów pracy wybranych czujników pola magnetycznego. Przegląd Elektrotechniczny 90(12):273-276

Quadroni S, Bettinetti R (2017) Health risk assessment for the consumption of fresh and preserved fish (Alosa agone) from Lago di Como (Northern Italy). Environ Res 156:571-578. https://doi. org/10.1016/j.envres.2017.04.018

Regulation of the Minister of Health of 7 December 2017 on the quality of water intended for human consumption. Dz.U. 2017 poz. 2294

Reindl AR, Bolałek J (2018) Organochlorine contaminants in the Vistula Lagoon sedimentation zone as possible source of lagoon recontamination. Environ Monit Assess 190(7):442. https://doi. org/10.1007/s10661-018-6804-2

Renault T (2011) Effects of pesticides on marine bivalves: what do we know and what do we need to know? In: Stoytcheva M (ed) Pesticides in the modern world: risks and benefits. ISBN: 978953-307-458-0. https://doi.org/10.5772/19155 
Rodrigues ET, Alpendurada MF, Ramos F, Pardal MÂ (2018) Environmental and human health risk indicators for agricultural pesticides in estuaries. Ecotoxicol Environ Saf 150:224-231. https:// doi.org/10.1016/j.ecoenv.2017.12.047

Rohr JR, Sesterhenn TM, Stieha C (2011) Will climate change reduce the effects of a pesticide on amphibians? Partitioning effects on exposure and susceptibility to contaminants. Global Change Biol 17(2):657-666. https://doi.org/10.1111/j.1365-2486.2010.02301.x

Roszko MŁ, Kamińska M, Szymczyk K, Jędrzejczak R (2016) Levels of selected persistent organic pollutants (PCB, PBDE) and pesticides in honeybee pollen sampled in Poland. PLoS ONE 11(12):e0167487. https://doi.org/10.1371/journal.pone.0167487

Sancho E, Villarroel MJ, Andreu E, Ferrando MD (2009) Disturbances in energy metabolism of Daphnia magna after exposure to tebuconazole. Chemosphere 74(9):1171-1178. https://doi. org/10.1016/j.chemosphere.2008.11.076

Satyavani G, Gopi RA, Ayyappan S, Balakrishnamurthy P, Reddy PN (2011) Toxicity effect of expired pesticides to freshwater fish, Labeo rohita. J Agric Environ 12:1-9. https://doi.org/10.3126/ aej.v12i0.7557

Schuld M, Schmuck R (2000) Effects of Thiacloprid, a new chloronicotinyl insecticide, on the egg parasitoid Trichogramma
Cacaoeciae. Ecotoxicology 9(3):197-205. https://doi. org/10.1023/A:1008994705074

Serrano R, Portolés T, Blanes MA, Hernández F, Navarro JC, Varó I, Amat F (2012) Characterization of the organic contamination pattern of a hyper-saline ecosystem by rapid screening using gas chromatography coupled to high-resolution time-of-flight mass spectrometry. Sci Total Environ 433:161-168. https://doi. org/10.1016/j.scitotenv.2012.06.042

Sousa JC, Ribeiro AR, Barbosa MO, Ribeiro C, Tiritan ME, Pereira MFR, Silva AM (2019) Monitoring of the 17 EU Watch List contaminants of emerging concern in the Ave and the Sousa Rivers. Sci Total Environ 649:1083-1095. https://doi.org/10.1016/j.scito tenv.2018.08.309

Yu L, Chen M, Liu Y, Gui W, Zhu G (2013) Thyroid endocrine disruption in zebrafish larvae following exposure to hexaconazole and tebuconazole. Aquat Toxicol 138:35-42. https://doi.org/10.1016/j. aquatox.2013.04.001

Zubrod JP, Bundschuh M, Schulz R (2010) Effects of subchronic fungicide exposure on the energy processing of Gammarus fossarum (Crustacea; Amphipoda). Ecotoxicol Environ Saf 73(7):16741680. https://doi.org/10.1016/j.ecoenv.2010.07.046 